\title{
Higgs boson and the Cosmos: A philosophical reappraisal of the authoritative Catholic and Greek-Orthodox perspectives
}




\section{Dimitris Kilakos}

Sofia University, Faculty of Philosophy/National Hellenic Research Foundation, Institute of Historical Research

E-mail:dimkilakos@hotmail.com

\section{Abstract}

The theoretical prediction of Higgs boson was arguably one of the most important contributions in particle physics in the $20^{\text {th }}$ century, with significant implications for modern cosmology. Its reported discovery in 2012 was celebrated as one of the most significant scientific achievements of all times. The fierce public discourse that followed was at large ignited by the media-hyped nickname "God particle" attributed to Higgs boson. The debate regarding the science-religion relation reinvigorated once again and plenty theologically informed views were expressed. In this paper, I take into consideration the authoritative views expressed by the Catholic Church and the Greek-Orthodox Church and I discuss them in comparison with each other, as well as in juxtaposition with other views expressed in the public discussion on the issue, in an attempt to draw philosophically interesting inferences. 


\section{Introduction}

There will probably be only a few (if any at all) physicists keen to disagree on that July 4, 2012 signals one of the most significant milestones in modern physics. It was then that the leaders of the ATLAS and CMS experiments at CERN's Large Hadron Collider announced that during their experiments, they had observed a previously undetected particle in the mass region around $126 \mathrm{GeV}$. According to the announcement (and further confirmed by other scientific reports that followed), this particle was consistent with the Higgs boson, the lynchpin of the Standard Model. On March 14, 2013 CERN confirmed the discovery of the Higgs boson.

The significance of the findings of CERN researchers is also highlighted by the fact that on 8 October 2013, the Nobel prize in physics was awarded jointly to François Englert and Peter Higgs "for the theoretical discovery of a mechanism that contributes to our understanding of the origin of mass of subatomic particles, and which recently was confirmed through the discovery of the predicted fundamental particle, by the ATLAS and CMS experiments at CERN's Large Hadron Collider".

In short, the announced discovery confirmed the Standard Model of particle physics, one of the pillars of modern physics, as the correct theory of elementary particles and their interactions; the Higgs boson was the last missing piece of the Standard Model. To put it as simply as possible, the Higgs boson is thought to be the essential 'building block' which allows matter to obtain mass. In a slightly more detailed and hopefully still accessible to non-specialists account, the Higgs boson is associated with an invisible field permeating throughout all of space and interacting with other particles to give them mass.

The existence of Higgs boson was theoretically predicted by Peter Higgs back in 1964, but it had not been detected until 2012. For almost 50 years, the quest for it had arguably set the discussion in particle physics for the last part of the 20th century, as well as in the first decade of the 21st century. If its discovery is considered to be the most important scientific achievement in modern physics in the 21st century, then it could be retrospectively inferred that its theoretical prediction in the 1960s was also of tremendous importance. Theoretical physics was not only able to predict the existence of the new particle and its properties, but also to calculate the rates at which it should decay into various combinations of other particles. In fact, this theoretical achievement was so impressive, that more than five decades from it, theoretical physics has no similar prediction at its disposal that have yet to be tested - at least according to several leading scientists. Under this prism, Higgs boson may serve as an exemplary case on how theoretical and experimental science can interact and inform each other.

The significance of the discovery is further underlined by its impact on modern cosmology. By understanding why matter has mass and what sort of interactions occur between parti- 
cles, scientists may be provided with clues that will further inform their quest for a better understanding of cosmic processes. Higgs physics is wide-ranging, and gives an impetus to go beyond the Standard Models of particle physics and cosmology to explore the physics of ultra-high energies and quantum gravity (Moss 2015). It has been proposed that the Higgs field of the Standard Model may have played an important role in cosmology, leading to the homogeneity, isotropy and flatness of the Universe; producing the quantum fluctuations that seed structure formation; triggering the radiation-dominated era of the hot Big Bang; and contributing to the processes of baryogenesis and dark matter production (Shaposhnikov 2015). Therefore, by attaining a more complete understanding of particle interactions due to Higgs boson, scientists may be able to proffer an enhanced understanding of the future of the universe. Indeed, the announcement of the discovery of Higgs boson was followed by the rising and development of a new field of scientific research, namely Higgs cosmology. The Higgs field itself has unique properties that may have allowed it to play a central role in the evolution of the Universe, from inflation to cosmological phase transitions and possibly to determine its ultimate fate through the electroweak vacuum instability (Rajantie 2018). In extremis, it could be argued that the possibility of Higgs boson collapsing on itself could mean the collapse of the universe as it will be by then.

It should have been obvious thus far why the announcement of the discovery of Higgs boson was received with overt enthusiasm by scientists. Yet, something seemingly unexpected also happened. All of a sudden, particle physics became front page news. People with almost total ignorance of particle physics were fervently talking about the reported discovery. However, this frenziness is not inexplicable, since it was triggered by the connotations following the media-hyped nickname which assigned to Higgs boson: the "God particle". ' It is not surprising that many people are more eager to get engaged fervently in a discussion about God and religion than in a discussion about bosons, leptons, quarks etc.

Indeed, scientific affairs with a tint of religious interest have more than once trigger vibrant and perky discussions. These discussions typically evolve around the "science vs. faith" dichotomy, with severe controversies regarding the issue of compatibility of scientific knowledge with religious belief. Although there are serious scholar voices calling for the mutual interaction of science and theology, grounded on the distinction between their fields of inquiry, it is not them that ordinarily give the pace on the relevant public discourse.

This is also the case for Higgs boson. It is true that, as we shall see in a while, most of the official representatives of both Catholic Church and Greek Orthodox Church, on which this paper focuses, were temperate in their commentaries about the announcement for the

1 It would be quite unfair to blame the Nobel Prize-winning physicist Leon Lederman, who introduced the term "the God particle" in the title of one of his books (Lederman and Teresi 1993), for the extent of this public discourse. 
discovery of Higgs boson. It seems, however, that they failed to set the tone in the theological speculations with which the relevant public discourse became engaged.

This paper focuses on various aspects of the public discourse on the issue from a philosophical perspective and attempts to draw philosophically significant inferences by them, as well as by the contradistinction of them with authoritative views propounded by representatives of the Catholic Church and the Greek Orthodox Church. Finally, in the concluding section of this paper, I will attempt to draw some conclusions regarding the public understanding of the relation between science and religion on the grounds of the theological views endorsed by both Churches. Extending this discussion with respect to other religious dogmas deserves further scholar work.

\section{The "God particle" in public discourse}

The vast majority of both natural scientists and theologians acknowledge that the Higgs boson does not have (and could not have) any specific religious connotations. However, this ascertainment was not sufficient to prevent the ignition of lively public discussions in which religious views were interlaced with interpretations of scientific achievements. ${ }^{2}$

Since theories of particle physics are extremely complex and a deep understanding of them and their implications requires special study, it is not a surprise that the public discussion was mainly informed by a rather simplified and quite often distorted understanding of the actual content and the importance of the reported discovery.

Such an understanding comes in a great variety of versions. I will attempt to codify a condensed and representative elaboration on some of them. Higgs boson is claimed to be the touchstone to the beginning of the universe, the formation of life and the fate of existence in general. Therefore, its reported discovery is thought to underpin scientific accounts for the constituents of existence itself and to serve as a means for a rational explanation for everything that has ever happened in the universe, including its creation. On these grounds, scientifically informed challenges to religion were anticipated, as well as

2 For an account on the correlations that could be established between scientific terms and religious expressions due to alternative interpretations of real physical processes, see Stahlberg 2015. For an account on the popularization of Higgs boson in British press, see Incelli 2018. For an account on how the scientific reports on the discovery of Higgs boson was blended with religious insights in media, see Surugiu 2013 for a case-study in Romania and Váňa 2015 for a case study in Czech Republic. In the rest of this section, the views I am treating are the ones reported in these works, as well as those that I came across with in Greek media. 
theological speculations responding to them. The issues raised in this discussion were the typical ones, e.g. regarding why and how the universe came into existence, what is God's role in its development, how God interferes with the world etc.

By focusing on those who proffered theological speculations, one could divide most of them in two camps: those attempting to elaborate a theological framework suitable for their understanding of the reported scientific achievement and those seizing the opportunity to argue against religion on the grounds of this achievement.

The first of the aforementioned two camps is populated by people with contrasting views regarding their reaction to the announced discovery of Higgs boson. On the one hand, there are the skeptics and the deniers, those who doubted or even rejected the discovery sweepingly, disregarding any scientific claim supporting it. On the other hand, there are those who argue that the universe was created by the hand of God and if the Higgs boson was part of the method employed by God, then so be it. For example, Philip Clayton, dean of Claremont School of Theology and researcher of science and religion notes that the awe we feel with this heady topic causes nonreligious people to use religious language and underscores that " $[t]$ he fans and the foes of religion [...] are overreaching on both sides. The quest for the Higgs boson, and its ultimate discovery, neither proves nor disproves God" (Clayton 2012). In this line of reasoning, the existence of a certain particle could not serve as a proof or disproof of God's existence; instead, it could be argued that God caused the particle to exist. Moreover, some of them argue that God is simply waiting for us to discover more of what he has made; thus, any new discovery, including Higgs boson, adds further admiration for the beauty and complexity of God's creations.

A logically analogous argumentation is propounded by those populating the second camp. According to them, the discovery may serve to make our understanding on how the universe became as it is known more solid, rendering the need to appeal to God's existence and interference with the world even more unavailing and ineffective than before this achievement. For example, Lawrence M. Krauss, an Arizona State University theoretical physicist argued in Newsweek that the Higgs boson discovery "posits a new story of our creation" independent of religious belief (Krauss 2012). In a much more provocative way, Peter Atkins of Cambridge University, claimed on BBC that the Higgs boson is "another nail in the coffin of religion". ${ }^{3}$

What is common in both camps, is that they turn to either religion or natural sciences, respectively, to argue for a philosophical issue: science is not meant to provide any evidence for or against God's existence and interference with the world, whereas any religion is

3 "The Higgs boson is another nail in the coffin of religion". BBC News Online Video. Posted on bbc.co.uk July 4, 2012. Accessed on August 20, 2018. 
grounded on the belief to God's (in the case of Christianity) existence and theology is meant to account for God's interference with the world. In any case, though, it is philosophy that is meant to deal with the questions regarding our understanding and conceptualization of the universe (as a whole) and God's existence. Therefore, the efficacy of the dialogue between science and religion in the aforementioned context, which prevails in public discourse, is being sapped from this very context.

Religiously inclined skeptics about science, though, may (and, actually, plenty of them do) adopt a different line of reasoning, worthy of further discussion. In the case of Higgs boson, they underscore that physicists have worked in their research as if this specific particle existed, even if there was no actual empirical evidence of its existence for almost 50 years from its theoretical introduction. Therefore, skeptics argue, scientists' belief in its existence was nothing more than plain faith, similar to religious faith. Belief without empirical evidence, then, according to this argumentation, is not an issue only for religion, but also for science. From a philosophical standpoint, though, this argumentation implies the adoption of an empiricist/positivist epistemological stance. ${ }^{4}$ Interestingly, it is the same stance that hailed (natural) science as the only reliable cognitive endeavor and undermined the validity of any non-scientific claim, including religious ones; on this ground, the forefathers of such a stance proclaimed the repudiation of any metaphysics. It is therefore noteworthy that those who are skeptic about science seem to endorse the same epistemological stance with those who are skeptic about anything else than science. Of course, it should be noted that this epistemological stance has been heavily criticized by several philosophical currents and is by no means the only one available. In any introductory book in epistemology one may find several other options.

In the public discourse about Higgs boson, skeptics about science have also deployed another argumentation. According to it, the reported discovery is untrustworthy, since the announcement was based only on indirect evidence of interactions, which were interpreted by scientists as if they were pointing to the discovery of Higgs boson, within the context of their theoretically biased research. This argumentation is meant to challenge the validity of scientific truth-claims and the power of human intellect to know the truth about the foundations of the world, since it is God who set up these foundations and human intellect is by its very nature unable to grasp God's reasoning and majesty. It is noteworthy that an analogous argumentation, emphasizing on contextualism (without appealing to God's reasoning and majesty, though), is employed by those theorists who attempt to deprive science

4 A noteworthy contribution from a different perspective is Peters and Peterson 2013, in which a physicist and theologian discuss the search a discovery of Higgs boson from the standpoint of critical realism and ask whether critical realism could constitute a set of presuppositions shared by both physicists and theologians who cannot see the object of their inquiry but employ conceptual models that presuppose the reality of its referent. 
of its credibility, contesting its truth-hunting practices. From a philosophical standpoint, this view stems from the endorsement of metaphysical relativism and subjectivism and is arguably heir to an eclectic mixture of several idealistic currents.

\section{Higgs boson and the Vatican}

In a strange coincidence, the announcement about the discovery of Higgs boson was made just two days after the election of the $112^{\text {th }}$ pope, Pope Francis I. Vatican's commentary on the discovery, given the provocative nickname that was given to Higgs boson, was expected by both religious and anti-religious militants. They did not have to wait for too long. The next day, in a July 5 interview with Catholic News Agency, ${ }^{5}$ Jesuit Brother Guy Consolmagno, a researcher and spokesman at the Vatican Observatory, hailed the scientific discovery as an important achievement. Br. Consolmagno said that the apparent discovery of the Higgs boson was a "delight", particularly given the gradual progress of most physical research, and the resources invested in running the particle accelerator. "It is nice to see such a big step occur that everybody can celebrate" the Vatican astronomer commented according to CNA, congratulating the researchers who "finally got something out of the years and time and effort they've put into it". As CNA reported, while the results from the Large Hadron Collider point to the discovery of this missing component in the Standard Model, Br. Consolmagno observed that there is "a hint that something else is going on" in the results, "which is always exciting". Br. Consolmagno was also precautious enough to clarify that the discovery, despite its nickname, "has nothing to do with theology or God" in any direct sense. As he reminded, the name 'the God particle' was basically a provocative title for book L. Lederman was writing on particle physics. "He said that if there was a particle that could exist that could explain all the little things we wanted to explain, it would be a gift from God. It is a metaphor and has nothing to do with theology", explained Br. Consolmagno.

A few months later, on October 2012, the XIII Ordinary General Assembly of the Synod of Bishops expressed a similar attitude. As it is reported in the Synodus Episcopicum Bulletin, ${ }^{6}$ H. Em. Rev. Card. Gianfranco Ravasi, President of the Pontifical Council for Culture, mentioned, among others:

"[...]There is, finally, the world of science and technology, now transversal in relation to every ethnic and cultural group, to which I would like to give specific consideration. The faith should not be afraid to penetrate this world [...]. Nowadays we look with

5 Retrievable from: https://www.catholicnewsagency.com/news/vatican-astronomersays-god-particle-is-misnamed-but-exciting (Accessed on August 20, 2018).

6 Retrievable from: http://www.vatican.va/news_services/press/sinodo/documents/ bollettino_25_xiii-ordinaria-2012/02_inglese/b12_02.html (Accessed on August 20, 2018). 
amazement also at the story of global evolution, from the primordial cosmic beginnings to the spiral of DNA, from Higgs-Boson to the multiverse. The incompatibility between science and faith and the prevarications of one against the other and vice versa, as has occurred in the past and continues to occur, should be replaced by mutual recognition of the dignity of their respective epistemological statuses: science is dedicated to the 'scene', that is the phenomenon, while theology and philosophy look to the 'foundation'. A distinction, but not of separateness to the point of reciprocal exclusion, since they have a single common object, that is, being and existence [...]. Dialogue is therefore indispensable, without arrogance and without confusion linked to specific levels and approaches".

It is noteworthy that, according to Synodus Episcopicum Bulletin, none of the other participants in the XIII Ordinary General Assembly of the Synod of Bishops mentioned anything about Higgs boson during the discussion. It seems reasonable, then, to infer that the attitude expressed by H. Em. Rev. Card. Gianfranco Ravasi is officialy endorsed by the Vatican. This inference arguably draws in further support if one takes into consideration other instances, in which Pope Francis expressed his views regarding the relation between religion and modern science. For example, in 2014, only two years after the reported discovery of Higgs boson, Pope Francis mentioned during his address to Plenary Session the Pontifical Academy of the Sciences:

"When we read the account of Creation in Genesis we risk imagining that God was a magician, complete with an all powerful magic wand. But that was not so. He created beings and he let them develop according to the internal laws with which He endowed each one, that they might develop, and reach their fullness. He gave autonomy to the beings of the universe at the same time in which He assured them of his continual presence, giving life to every reality. And thus Creation has been progressing for centuries and centuries, millennia and millennia, until becoming as we know it today, precisely because God is not a demiurge or a magician, but the Creator who gives life to all beings. The beginning of the world was not a work of chaos that owes its origin to another, but derives directly from a supreme Principle who creates out of love. The Big Bang theory, which is proposed today as the origin of the world, does not contradict the intervention of a divine creator but depends on it. Evolution in nature does not conflict with the notion of Creation, because evolution presupposes the creation of beings who evolve". (Pope Francis 2014)

Two years later, in 2016, once again in the occassion of his address to the Pontifical Academy of the Sciences, Pope Francis expressed his pleasure that "we are seeing a renewed partnership between the scientific and Christian communities, who are witnessing the convergence of their distinct approaches to reality in the shared goal of protecting our common home" (Pope Francis 2016).

Of course, it should be noted that views similar to the ones expressed by Pope Francis are 
not new for the Catholic Church. It has been six decades now that the Catholic Church, since the reforms of Pope Pius XII, has espoused belief in theistic evolution. As the International Theological Commission (ITC) of the Catholic Church stated in 2014, in "Communion and Stewardship: Human Persons Created in the Image of God", 7 the Church is relatively indifferent to the mechanism of the development of life; in talking about creation, Church's main concern is what the creation means for man. In the section on "The Creator" in the promulgated for the Catholic Church by Pope John Paul II in 1992 "Catechism of the Catholic Church", 8 it is stated that:

"283. The question about the origins of the world and of man has been the object of many scientific studies which have splendidly enriched our knowledge of the age and dimensions of the cosmos, the development of life-forms and the appearance of man. These discoveries invite us to even greater admiration for the greatness of the Creator, prompting us to give him thanks for all his works and for the understanding and wisdom he gives to scholars and researchers. With Solomon they can say: 'It is he who gave me unerring knowledge of what exists, to know the structure of the world and the activity of the elements [...] for wisdom, the fashioner of all things, taught me'.

284. The great interest accorded to these studies is strongly stimulated by a question of another order, which goes beyond the proper domain of the natural sciences. It is not only a question of knowing when and how the universe arose physically, or when man appeared, but rather of discovering the meaning of such an origin: is the universe governed by chance, blind fate, anonymous necessity, or by a transcendent, intelligent and good Being called 'God'? and if the world does come from God's wisdom and goodness, why is there evil? Where does it come from? Who is responsible for it? Is there any liberation from it?"

It seems, therefore, that the Catholic Church officially rejects the incompatibility between science and faith and supports the dialogue and even the interaction between them. The view on mutual interaction has been incorporated into the Second Vatican Council's Pastoral Constitution on the Church in the Modern World titled 'Gaudium et Spes', promulgated by Pope Paul VI on 1965:9

7 Retrievable from: http://www.vatican.va/roman_curia/congregations/cfaith/cti_documents/rc_con_cfaith_doc_20040723_communion-stewardship_en.html (Accessed on August 20, 2018).

8 Retrievable from: http://www.vatican.va/archive/ENG0015/__P19.HTM (Accessed on August 20, 2018).

9 Retrievable from: http://www.vatican.va/archive/hist_councils/ii_vatican_council/ documents/vat-ii_cons_19651207_gaudium-et-spes_en.html (Accessed on August 20, 2018). 
"By the very nature of creation, material being is endowed with its own stability, truth, and excellence, its own order and laws. These, as the methods proper to every science and technique must be respected. Consequently, methodical research in all branches of knowledge, provided it is carried out in a truly scientific manner and does not override moral laws, can never conflict with the faith, because the things of the world and the things of faith derive from the same God".

As Pope John Paul II suggested in the very beginning of his encyclical letter to the bishops of the Catholic Church on the relation between faith and reason, titled "Fides et Ratio", "[f]aith and reason are the two wings by which the human spirit rises to the contemplation of truth" (Pope John Paul II 1998). Furthermore, Pope John Paul II reminded that the First Vatican Council in Dei Filius reaffirmed the proper balance of faith and reason in theological inquiry.

The previous discussion is relevant to the reception of the announced discovery of Higgs boson by the Catholic Church, since it sets the context in which this scientific achievement was interpreted. Moreover, it is relevant since the reported discovery of Higgs boson was discussed -mainly in the public discourse and not in scientific debates- in the conjunction with the issue of the creation of matter ex Nihilo (from nothing) or in the transformation of existing mass-less virtual particles into matter in a Higgs field that theoretically encompasses the entire universe. ${ }^{10}$

Creation ex Nihilo was the central symbol by which the Church of the Fathers and the Middle Ages described the relationship between God and the physical world (Clifford 1991, 220). The doctrine of creation expresses the belief that God is the origin, ground, and goal of the world and everything within it (Clifford 1991, 195). This doctrine has been central in several discussions throughout the history of the Vatican Church. For my current purposes, it suffices to note that the First Vatican Council reasserted that all reality happens by the "free initiative of God's love" and Vatican II restated the centrality of Creatio ex Nihilo in "The Mystery of the Church", which is the first Chapter of the Dogmatic Constitution on the Church, Lumen Gentium, which was solemnly promulgated by Pope Paul VI on 1964."

Arguably, the most significant challenge to Creatio ex Nihilo was biological evolution, an issue on which there is vast literature, reviewing which lies far beyond the scope of this paper. In any case, it should have been obvious to the reader that it is not a surprise that the discussion on Higgs boson has been intersected with the one on evolution of (and in) the universe.

10 For a detailed discussion on Creation Ex Nihilo with regard to the discovery of Higgs boson, see Rozos 2013.

11 Retrievable from: http://www.vatican.va/archive/hist_councils/ii_vatican_council/ documents/vat-ii_const_19641121_lumen-gentium_en.html (Accessed on August 20, 2018). 


\section{Higgs boson and the Greek Orthodox Church}

In order one to understand the ambiguity of the views propounded by representatives of the Greek Orthodox Church with regard to the reported discovery of Higgs boson, s/he should take into consideration the argumentation grounded on Orthodox patristic theology about the boundaries between science and theology and the possibility of interaction between them. Although this argumentation points to similar conclusions with those drawn by the Catholic Church, the reasoning that leads to them differs.

According to the Rev. Metropolitan of Nafpaktos and St. Vlassios Hierotheos, theology in the West was identified with metaphysics, whereas Orthodox theology, as expressed by the Fathers of the Church, is anti-metaphysical. As he explains, while metaphysics (western Christian metaphysics included) is concerned with metaphysical and natural phenomena and maintains that natural beings are copies of the metaphysical ones (in a form of neo-platonism, consanguineous from this perspective to neo-thomism), Fathers of the Church refer to uncreated (God) and created beings (the whole of nature, which was created by God and it is not a copy of ideas). Therefore, for Orthodoxy, there is no dialectical distinction between metaphysical and natural beings, as if the metaphysical ones reside in a floor above the natural ones. Instead, God's uncreated energy meets the created energy of the created things. In this line of reasoning, there is no ontological relation between the ideas of God and those of the creatures. The world came to existence out of non-existence. From an Orthodox theology point of view, the advances of natural sciences cause no theological problem, because scientific discoveries do not undermine man's relationship with God, since the creation is not a copy of ideas. Therefore, due to the rejection of metaphysics, Orthodox theology has no essential problem with the advances of modern science, unless science goes beyond its boundaries (Hierotheos of Nafpaktos 2013).

On these grounds, it is argued that there can be no conflict between modern science and Orthodox theology, while it is well known that such a conflict developed in the West. However, one could counter-argue that there have been several incidents of such a conflict in Greece, even if it could be argued that they resulted from a distorted understanding of the Orthodox patristic theology. In fact, views pointing to such a conflict were expressed in the case of Higgs boson.

The first public statement from a member of the hierarchy of Greek Orthodox Church was arguably the most characteristic case. In an official statement ${ }^{12}$ just a few hours before the announcement regarding the discovery of Higg's boson in CERN, the Rev. Metropolitan of

12 Retrievable from the official website of the Metropolis of Piraeus: https://www.imp. gr/2012-03-27-20-22-23/62-2012-07-04-16-55-05.html (Accessed on August 20, 2018 - in Greek, my translation). 
Piraeus Serapheim discusses several theories and concepts of modern physics (i.e. string theory, gravitational singularity, quantum chaos etc.), suggesting that:

"[...] all of them attempt to interpret the phenomenon of life without any reference or even by rejecting and abhorring Him who is above all being in a hyperessential mode [ton hyperousion], Holy God, thus proving themselves to be heterogeneous neuropaths of the ancient demon, altering science from truth and gloom in cunning and perversion, because they attempt to persuade that order, harmony, thinking, telonomy, purposefulness and overt wisdom governing the material Universe originate from changes and unconscious units of matter, which, as it is suggested, acted and are still acting due to randomness".

With specific regard to Higgs boson, Metropolitan Serapheim stated that "brilliant minds in CERN" attempt to persuade us that it, "being an unconscious unit of energy, if it exists", creates and coordinates the trillions of galactic formations, the natural laws governing them, the eternal motion of "matter-mass" in the universe, the life of beings. Moreover, they attempt to persuade us that this "unconscious particle, which cannot answer the question 'what are you?'", creates from nothing conscious human beings and transcends the unsurmounted chasm between organic and inorganic matter. According to the Metropolitan Serapheim, such a belief is nothing more than "cretinism". He further notes that such "terrible and ignominious for human personality, human history and human philosophy views" mask the "obnoxious face of demonism, since only demons and those possessed by them may fudge this kind of absurdities".

As it may be expected, the exposition of such views by one of the 82 hierarchs tending holy Metropolitanates of the Greek Orthodox Church ignited fierce responses, forcing the Metropolitan Serapheim to issue a new official statement, ${ }^{13}$ in which he reassures that the previous one was not meant to attack science, since "science is a product of reason, which is given to human by God". Arguing that the previous statement was about the "deified" interpretation of the reported discovery of Higgs boson "not on the scientific level, but on ethical, existential, spiritual and philosophical one", he further comments that scientifically researching the creatures of God's wisdom is praiseworthy, but "attributing it to nothing and no one, to the unconscious, impersonal and irrational matter is impudence and demonism". In an attempt to support these views, he employs argumentation typically employed in the "evolution vs. intelligent design" debate, attempting to argue by the force of several examples that any rational man could not attribute the harmony in the universe to any "irrational and unconscious unit of energy or any irrational and unconscious natural selection". It should be noted that the views expressed by Metropolitan Serapheim regarding the re-

13 Retrievable from the official website of the Metropolis of Piraeus: https://www.imp.gr/ 2012-03-27-20-22-23/63-cern.html (Accessed on August 20, 2018 - in Greek, my translation). 
ported discovery of Higgs boson were not officially endorsed by the Greek Orthodox Church. Several other members of the hierarchy expressed distinctly different views. Some of them (i.e. the Rev. Metropolitan of Alexandroupolis Anthimos, the Rev. Metropolitan of Messinia Chrysostomos etc.) opposed in public the views expressed by Metropolitan Serapheim, pointing to that theology and the Church should not demonize scientific achievements, since the latter cannot, a priori, diminish God's role in the creation of the universe. Others attempted to explain the significance of the discovery in the context of modern physics and especially with regard to Big Bang theory.

A noteworthy contribution to this discussion is an article written by Metropolitan Hierotheos, who appeals to the famous American Christian physician-geneticist F. Collins (leader of the Human Genome Project and director of the US National Institutes of Health) and D. Nanopoulos (one of the most cited high-energy and particle physicists and cosmologists) to explain the significance of the reported discovery for modern cosmology and to St. Gregory of Nyssa to theologically explain how the discovery should be interpreted with regard to the relation between science and religion. According to him, human science attempts to interpret how the world was created, whereas the most important issue is who created both human and the world, a question beyond the scope of sciences. Furthermore, with regard to Higgs boson and Higgs field, he emphasizes on that there is a great difference between referring to it as "God's particle" and "God particle". As he explains, "it is different to claim that it is a way by which God created the world than to claim that this energy and matter is god. In the second occasion, not only is man guided to agnosticism and atheism, but also endorses materialism, that matter is the beginning of the world" (Hierotheos of Nafpaktos 2012).

The media-hyped nickname "God particle" is also the focus of the short commentary by the Rev. Metropolitan of Messogaia and Lavreotiki Nikolaos, ${ }^{14}$ who stresses on that "as it appears, our knowledge is confined, disproportionately to our arrogance, which is unlimited". Interestingly enough, he further suggests that "the characterization 'God's particle' would be more suitable for the photon, for which God himself spoke, when saying "let there be light" and light appeared" (Nikolaos of Messogaia 2012).

The views expressed by the Metropolitan Nikolaos are of significant importance, since he, being a member of the Standing Holy Synod of the 155th Synodical Period (2011-2012) of the Greek Orthodox Church, was the one assigned to speak on the Church-science relation in the Regular Synod of the Hierarch of Greece on October 2012, only a few months after

14 Rev. Nikolaos' scientific background is noteworthy. He studied physics at the University of Thessaloniki and continued his postgraduate studies (MA) in astrophysics at Harvard University and in engineering and biomedical engineering (DPhil) at MIT. 
the announced discovery of Higgs boson. In his speech, ${ }^{15}$ he acknowledged the "explosive development of science", which led to impressive new knowledge and admirable applications. "The universe, which was previously considered to be limitless and incomprehensible, seems to have become less mysterious", as he mentioned. With regard to the reported discovery of Higgs boson, he stated:

"The recent experiment in CERN proved how easily scientists could get deceived and how often smart people are proven naive. All this just because it seems that somehow it is explained how mass appeared in the universe (Higgs boson's field) or a theory interpreted its beginning (big bang), by Lemaitre, a catholic monk".

According to Metropolitan Nikolaos, there are some scientists who take advantage of "pompous" (i.e. creation of life and universe, theory of everything) or "metaphysical" (i.e. strange quark, God's particle) terms to blend their personal views with scientific inferences and to deceive naive people, persuading them to espouse a mixture of "scientific verisimilitude, personal shallowness and stupid arrogance, which destroy every element of sacredness in man and in our world". In any case, though, Metropolitan Nikolaos reassures that Orthodoxy should not be afraid of science. As he explains:

\begin{abstract}
"The problems that seemingly exist are exclusively due to the western view on faith, which, being dangerously and untheologically rationalized, interprets the mystery of the world, of life and of human in a narrow way and looks each time for abutments in the scientific achievements. Modern science is not a danger for our faith. Contrariwise, it confirms it - in fact festively, as it is lived by our Orthodox Church. One could write nowadays a wonderful Hexaimeron, using the amazing findings of modern physical and biological sciences, not on the grounds of the literal agreement of science with the book of Genesis, which ostensibly "proves" the existence of God, but on the grounds of an impressive compatibility of modern scientific cosmology and anthropology with Orthodox theology and its apophatic character [...]".
\end{abstract}

\title{
Prospects of a comparative discussion
}

In the speech he delivered at the Regular Synod of the Hierarch of Greece on October 2012, which has been referred to at the previous section, Metropolitan Nikolaos raises three more points which arguably expedite setting up the context for a comparative discussion of the authoritative views on the announced discovery of Higgs boson of the Catholic Church and

15 Retrievable from the official page of the Greek Orthodox Church: http://www.ecclesia. gr/greek/holysynod/lavreotikis_2012.pdf (Accessed on August 20, 2018 -in Greek, my translation). 
the Greek Orthodox Church.

At first, Metropolitan Nikolaos invokes a quotation from Plato in Menexenus ("any science without justice and other virtue looks like slyness and not wisdom") to support his argumentation. However, as it has already been discussed, Metropolitan Hierotheos argues that Plato's philosophical reasoning is incompatible with the Orthodox patristic theology. It seems then, that there might be a slight tension between the two views, worthy of further discussion. From a philosophical perspective (and ignoring any theological considerations), it could be argued that the sort of copy-theory (that natural beings are copies of the metaphysical ones) which is rejected by Metropolitan Hierotheos could be compatible with the Christian doctrine that God created man in His own image. Therefore, appealing to Platonism for philosophical insights does not seem unjustifiable for an Orthodox thinker. However, from an Orthodox theological perspective, the situation is different. In the official dogmatic text of the Orthodox Church known as the "Synodicon of Orthodoxy" is "codified the age-old, holy patristic stance which differentiates between the study of Hellenic Philosophy -that is, its educational usage- and the acceptance of its theology" (Metallinos 2003, 53-54). Obviously, this is applicable to Plato's philosophy, too. Thus, the theology of Plato and other ancient Greek philosophers is condemnable for the Orthodox Church, whereas their philosophy is useful only as an educational resource and their philosophical vocabulary as linguistic formulations. Therefore, theologizing platonic philosophy is not acceptable for Orthodoxy. For example, while Plato talks about the immortality of the soul, if one is keen to ascribe theological significance to this platonic view, s/he will contradict the patristic interpretation of the Bible, according to which there exists nothing else than divinity (God, the Holy Trinity) and creation (all else apart from God); therefore both the material and the spiritual (including soul) world are created (Matsoukas 2005, 194). Therefore, our short discussion on the ostensible tension between the views expressed by Metropolitan Nikolaos and Metropolitan Hierotheos, points to an interesting direction. It could be argued that the science-religion debate is orthogonal to the philosophy-theology debate, whereas philosophy, as it is well known, was forced throughout the centuries to redefine itself and adjust its subject-matter with regard to the development of science.

Secondly, in the same speech, Metropolitan Nikolaos seems to adopt the anthropic cosmological principle, according to which, as he explains, "the values of the global constants are so that they necessarily lead to the appearance and life of human on earth". In fact, he proceeds even further, by arguing that rejecting the anthropic principle and believing, instead of it, that "the material world, the universe, is the outcome of randomness, which means that it accrued from nothing without God's intervention" contrasts the Christian doctrine that "we are created from God", that God created man in His own image. Being fundamentally teleological, the anthropic cosmological principle arguably has its philosophical roots in the works of Fichte and Hegel, with Bergson and Teilhard de Chardin being some of the most influential philosophers in $20^{\text {th }}$ century propounding similar ideas.

Notably, though, Christian theology has not always been comfortable with assimilating 
their line of reasoning; the case of Teilhard de Chardin is quite characteristic and thoroughly discussed, ${ }_{1}^{16,17}$ while Christian philosophers are also not unanimous on the anthropic principle. One of the most influential and respectable philosophers of science in the $20^{\text {th }}$ century, E. McMullin, who was ordained a Roman Catholic priest in 1949, elected president of the American Catholic Philosophical Association and served as a member of the executive committee of the Society of Christian Philosophers, in his (McMullin 1994) argued against the anthropic cosmological principle on philosophical grounds. On the contrary, other Christian philosophers (i.e. W.L. Craig, J. Polkinghorne etc.) and scientists (i.e. G. Ellis) argue that the anthropic principle is compatible with divine design and arguably supporting theism - Ellis even suggests that a "Christian anthropic principle" as the basis for an ultimate understanding of the universe that combines scientific and religious perspectives (Ellis 1993). ${ }^{18}$ From an Orthodox Christian perspective, it has been argued that the anthropic cosmological principle does not contradict orthodox patristic theology, since the Fathers of the Church have explained the human being as the key to the universe on theological premises. From this point of view, it could actually be argued that the anthropic principle has always been central to patristic theology. On these grounds, it is argued that the fact that man is the highest being in the universe, as well as that the intelligence of the universe is related to the intelligence of the human being, is proven by the Incarnation. Since God, who created the universe, not only created man in His image, but actually became a human being Himself by taking to Himself the human form of being, human being has been confirmed as the highest life form in the universe, and furthermore, as the key to the universe [for a detailed

16 The pre-Vatican II Church issued a warning on Teilhard de Jardin's writings, although his works were not included in the Prohibited Index, up to its abolition in 1966. In his book The Spirit of the Liturgy Pope Emeritus Benedict XVI (then J. Ratzinger) considers Teilhard de Jardin's theological vision of Christ to be central to the Christian liturgical and Eucharistic experience. On the contrary, from an Orthodox perspective, Fr. Seraphim Rose renounces Teilhard de Jardin as a prophet of the Anti-Christ (Rose 1975; 2000). For the contrasting views on the theological interpretations of Teilhard de Jardin's work see, among others, von Hildebrand 1967 and Stafford Wright 1975, who are criticizing Teilhard de Chardin views from a theological and philosophical perspective, while Grummett 2005 attempts to reclaim him as a French catholic theologian.

17 Given the main focus of this paper, on how the reported discovery of Higgs boson was interpreted by authoritative Christian views, it is interesting to note that in one of Teilhard de Chardin's most interesting books, Hymn of the Universe (de Chardin 1961), Chapter One was entitled "The Mass on the World". Discussing his views on the issue in comparison with the views expressed on behalf of the Catholic Church with regard to the reported discovery of Higgs boson is an interesting topic, requiring further scholar work.

18 An interesting discussion on the anthropic principle and its possible theological implications is proffered by Fr. George Coyne, S.J., Director of the Vatican Observatory from 1978 to 2006 (Coyne 1993). 
discussion, see Dragas 2016)].

It should be noted that the anthropic cosmological principle is directly linked with the argumentation in favor of "Intelligent Design". Interestingly enough, argumentation relevant to the one adopted by the proponents of Intelligent Design has been employed also by Metropolitan Serapheim, in his second statement about the reported discovery of Higgs boson, as it has already been discussed. This issue retains its interest, given another quote from the aforementioned Metropolitan Nikolaos' speech, according to which people nowadays seem to prefer

"[...]materiality or randomness, the ephemeral character and the animality of human nature, in order to overthrow its divine origin. A man powerful as a dinosaur, with a past as an ape, with an origin as an amoeba, zero being the prospect for him, mortal god himself, without the mystery of the eternal God in him or His presence around $\operatorname{him}[\ldots]]^{\prime \prime}$.

Even if the Greek Orthodox Church has not been officially got engaged with the "evolution vs. intelligent design" debate, it is noteworthy that arguments employed in this discussion appear in official statements and speeches delivered in the Holy Synod of the Greek Orthodox Church, both of them dealing also with the case of Higgs boson.

Finally, there is one more interesting point raised by Metropolitan Nikolaos in his speech. As he vividly mentions, referring to contemporary human, "[i]nebriated by the achievement of the technologization of the world, we lost interest regarding Who and how created it. The glory of human success annihilated the glory of God, the creator". While this view seems theologically sound, it should be noted that it is in apparent contradiction with the aforementioned argumentation deployed by Metropolitan Hierotheos who, by appealing to St. Gregory of Nyssa, argues that human science attempts to interpret how the world was created, whereas the question regarding who created both human and the world is beyond the scope of sciences. In short, the apparent tension between the two views is on whether the "how" of creation is a subject-matter of science or religion. Of course, it could be argued that science and religion offer answers on this question from their distinct perspectives. However, from a philosophical perspective, such a view is arguably troublesome. For, if theology is to be involved in the discussion of the "how-question", then it is silently implied that the "who-question" is already answered, in the sense that it is taken for granted that the world/universe/cosmos was actually created by a divine entity. If, in turn, the answer to the "who-question" is taken for granted, then it is logically unclear why the "how-question" should be answered in a different way than something like "according to God's will". If this is so, then, it is arguably theologically puzzling to account for God's will and explain God's actions in terms of natural sciences. Moreover, in this context, someone could plausibly raise the question why God acted in this particular way and not in another. However, it is questionable how, and even if, theology could render God's will comprehensible to human rationality. Therefore, if one is willing to account for a distinction between what is theolog- 
ically significant regarding the "how-question" and what is of interest for natural sciences, then s/he should somehow address the aforementioned issues; from a philosopher's point of view, it is rather vague whether such an account could be logically coherent.

The same issue begets further discussion from a slightly different perspective. As it has already been argued, it seems to be question-begging to ask whether the "how-question" regarding the creation of the world is to be answered by the natural sciences or not, if it is a priori proclaimed that creation actually happened (instead of, for example, eternal evolution in infinite space and time). Philosophy has addressed this same issue a long time ago. For example, Plato writes in Timaeus (28b): "Now everything that becomes or is created must of necessity be created by some cause, for without a cause nothing can be created [...]Was the world, I say, always in existence and without beginning, or created, and had it a beginning?"

In fact, attempts to answer this question have been deployed even before Plato and, obviously, after him. Among them, several philosophers disavowed the very nature of the "who-question". For example, the pre-Socratic lonian philosopher Anaximander considered being to be primary in an indefinite past, while at the same time he invoked 'apeiron' (a hypothetical and logically prior stuff) in his account, attributing to it the sole property of being the primary stuff. Or, more than 20 centuries later, Spinoza argued that, while anything else is determined by the action of an external cause, Nature, as a whole, is causa sui. Of course, these views have been put in philosophical scrutiny and there is much that could be said about them. However, such a discussion is far beyond the scope of this paper.

The argumentation in these paragraphs was just meant to point to that, next to the theologically and scientifically interesting issues raised by the "how-question" and "who-question", there are also philosophically significant issues that should not be overlooked, even if interlocutors in the relevant debates are rarely keen on addressing them as such. In the aforementioned context, the case of the reported discovery of Higgs boson is indicative for the need of such a discussion.

\section{In lieu of conclusion}

Despite the differences between them, both authoritative views discussed in the previous sections of this paper (by the Catholic Church and the Greek-Orthodox Church) welcome this scientific achievement as one that seems to confirm a significant part of some of the best available up to now theories about worldly processes; thus, both of them maintain that the reported discovery of Higgs boson is a significant contribution in our attempt to disclose, via science, some previously unknown aspects of the God-created world. However, if one takes into account the differences between them, as well as the differences between other views expounded within the Catholic and the Greek-Orthodox Church and also by other, religiously-minded participants in the public discourse on the issue, it seems that the question on if/how we are able to apprehend, by our cognitive capacities, God's 
creation begets further discussion. In this discussion, philosophy should be engaged on its own merits, next to theology and natural sciences.

In the Kantian line of reasoning, for example, one could argue for our knowledge (of the worldly processes explained by the invocation of Higgs boson, in this particular case) in terms of some kind of external manifestation of a certain, fundamentally inconceivable thing-in-itself. If one renders the aforementioned "how-question" theologically irrelevant, then a Kantian line of reasoning could arguably be applicable in attempts to philosophically justify such a view.

On the contrary, a Hegelian line of reasoning could be employed by someone who renders the "how-question" theologically interesting. For example, s/he could argue that human thought is attributed with the capacity of developing to the rank of supreme reality, since the laws of thought coincide with the laws of the absolute; thus human thinking apprehends the laws that absolute reason submits itself to.

However, any choice comes with its burden, since both the Kantian and the Hegelian line of reasoning have been effectively criticized by other philosophical currents. For example, a militant materialist would have probably made his/hers points and attitude clear at earlier parts of this discussion, rendering it pointless.

Other points could be raised from the standpoint of several philosophical traditions and currents.

In any case, though, the reception and discussion on the reported discovery of Higgs boson, both in public discourse and in ecclesiastical circles, point to one direction: is our intellectual capacity the best means at our disposal to guide our efforts, as social human beings, to find the truth about the world we live in? This is a genuine philosophical question from which any theological or natural scientific worldview cannot escape. To put it differently, any attempt to skip this question, renders any answer from both these sides deficient. The case of Higgs boson, as it has been discussed in the previous sections of this paper, vividly elucidates this point.

Research for this paper was funded by the ANAVATHMIS project. The project entitled "ANAVATHMIS. Historical research and digital applications" (MIS 5002357) is implemented under the "Action for the Strategic Development on the Research and Technological Sector", funded by the Operational Programme "Competitiveness, Entrepreneurship and Innovation" (NSRF 2014-2020) and co-financed by Greece and the European Union (European Regional Development Fund) 
• Clayton, P. (2012), "Does the Higgs boson discovery resolve the religion-science debate?", Huffington Post, 07/06/12: https://www.huffpost.com/entry/relationship-between-scie_b_1653976 (Accessed on August 20, 2018).

- Clifford, A.M. (1991), "Creation", in Fiorenza, F., Galvin, J. (eds), Systematic Theology: Roman Catholic Perspectives. Minneapolis: Fortress, 1: 193-248.

- Coyne, G.V. (1993), "Some Theological Reflections on the Anthropic Principle", in Bertola, F., Curi, U. (eds), The Anthropic Principle: The Conditions for the Existence of Mankind in the Universe. Cambridge: Cambridge University Press, 161-168.

- De Chardin, T. (1961), Hymn of the Universe. New York: Harper G Row.

- Dragas, G.D. (2016), "The Anthropic Principle: Christ's Humanity", in Dragas, G.D. (ed.), Orthodox Theology and the Sciences. Sofia: Sofia University Press G New Rome, 34-50.

• Ellis, G. (1993), "The Theology of the Anthropic Principle", in Russell, R.J., Murphy, N., Isham, C.J. (eds), Quantum Cosmology and the Laws of Nature: Scientific Perspectives on Divine Action. Vatican City State: Vatican Observatory, 367-405.

- Grummett, D. (2005), Teilhard de Chardin: Theology, Humanity and Cosmos. Leuven: Peeters Publishers.

- Hierotheos of Nafpaktos, Rev. Metr. (2012), "'Big bang theory' and 'Higgs boson'" (in Greek - my translation), Ekklisiastiki Parembasi (official newspaper of the Diocese of Nafpaktos and St. Vlassios) 192: 1-2.

- Hierotheos of Nafpaktos, Rev. Metr. (2013), "Theology and Science", Paper presented at the International Theological Conference in Sofia, Bulgaria, 2011, April 26-30. Retrieved from the website of the newspaper of the Diocese of Nafpaktos and St. Vlassios Ekklisiastiki Parembasi: http://www.parembasis.gr/index.php/menu-english-on-web/330-englishtheology-and-science (Accessed on August 20, 2018).

- Incelli, E. (2018), "Popularising the Higgs boson: a corpus-assisted approach to reporting scientific discovery in online media", Corpora 13(2): 169-203.

- Krauss, L.M. (2012), "How the Higgs boson posits a new story of our creation", Newsweek 07/09/2012: https://www.newsweek.com/how-higgs-boson-posits-new-story-our-creation-65567 (Accessed on August 20, 2018).

- Lederman, L., Teresi, D. (2013), The God Particle: If the Universe is the Answer, what is the Question? New York: Houghton Mifflin.

- Matsoukas, N.A. (2005), Universal Theology. Thessaloniki: Pournaras Publications.

- Metallinos, G.D. (2003), Paganist Hellenism or Hellenic Orthodoxy?. Athens: Armos Publications.

- McMullin, E. (1994), "Fine-tuning the Universe?", in Shale, M., Shields, G. (eds), Science, Technology, and Religious Ideas. Lanham: University Press of America.

- Moss I.G. (2015), "Higgs boson cosmology", Contemporary Physics 56(4): 468-476.

- Nikolaos of Messogaia, Rev. Metr. (2012), "A few words on God's particle" (in Greek - my translation), Retrieved from the official website of the Metropolitanate https://www. imml.gr/index.php?option=com_contentGview=articleGid=312:swmatidio-tou-theouG - 
catid=126 G Itemid=622 (Accessed on August 20, 2018).

- Peters, T., Peterson, C. (2013), "The Higgs Boson: An Adventure in Critical Realism", Theology and Science 11(3): 185-207.

- Pope Francis (2014), "Address on the occasion of the inauguration of the bust in honour of Pope Benedict XVI". Retrieved from: http://w2.vatican.va/content/francesco/en/speeches/2014/october/documents/papa-francesco_20141027_plenaria-accademia-scienze. html (Accessed on August 20, 2018).

- Pope Francis (2016), "Address to the participants in the plenary session of the Pontifical Academy of Sciences". Retrieved from: https://w2.vatican.va/content/francesco/en/ speeches/2016/november/documents/papa-francesco_20161128_pontificia-accademia-scienze.html (Accessed on August 20, 2018).

- Pope John Paul II (1998), "Fides et Ratio". Retrieved from http://w2.vatican.va/content/ john-paul-ii/en/encyclicals/documents/hf_.jp-ii_enc_14091998_fides-et-ratio.html (Accessed on August 20, 2018).

- Ratzinger, P. (2000), The Spirit of the Liturgy. San Francisco: Ignatius Press.

- Rajantie, A. (2018), "Higgs cosmology", Philosophical Transactions. Series A, Mathematical, Physical, and Engineering Sciences 376(2114), 20170128. http://doi.org/10.1098/ rsta.2017.0128

- Rose, S. (1975), Orthodoxy and the Religion of the Future. Platina: Saint Herman of Alaska Brotherhood.

- Rose, S. (2000), Genesis, Creation and Early Man. Platina: St. Herman of Alaska Brotherhood.

- Rozos, R.R. (2013), "Bridging Creation Ex Nihilo and Poesis: The Search for the Higgs Boson "God" Particle and the Renewal of Natural Theology". Retrieved from: https://www.academia. edu/7671114/The_Higgs_Boson_God_Particle_and_the_Renewal_of_Natural_Theology (Accessed on August 20, 2018).

- Shaposhnikov, M. (2015), "The Higgs boson and cosmology", Philosophical Transactions. Series A, Mathematical, Physical, and Engineering Sciences 373 (2032): 20140038. http:// doi.org/10.1098/rsta.2014.0038.

- Stafford Wright, J. (1975), "The Theology of Teilhard de Chardin", The Churchman 89(1): 33-46.

- Stahlberg, L.-0. (2015), "The Higgs Boson, The God Particle, and the Correlation Between Scientific and Religious Narratives", Open Theology 1: 366-378.

- Surugiu, R. (2013), "Science Reports and Religious Insights in Romanian National Media", European Journal of Science and Theology 9(5): 187-200.

- Váňa, J. (2015), Where does the "God" within the "God particle" come from? Cultural sociological analysis of the Higgs boson research. Master Thesis - Masaryk University, Faculty of Social Studies, Department of Sociology. Retrievable from: https://is.muni.cz/ repo/1321521/cena_ebenese_2015_vana.pdf (Accessed on August 20, 2018).

- Von Hildebrand, D. (1967), Trojan Horse in the City of God. Chicago, IL: Franciscan Herald Press. 